\title{
PELATIHAN GURU SMK MUHAMMADIYAH 4 SLIPI JAKARTA MENGENAI BUSINESS LETTER BERBAHASA INGGRIS
}

\author{
Rima Novia Ulfa* \\ Program Studi Pendidikan Bahasa Inggris, Universitas Indraprasta PGRI
}

\begin{abstract}
The aim of this study is to provide training on the technique of making a business letter in English for teachers of SMK Muhammadiyah Slipi Jakarta. Business letter is a letter that is used by a person, organization or institution that deliver business messages in writing to the other party by using a specific media whether it is sending via postal mail, faksmilie, telephone or the internet. The activity of writing a business letter is seen as simple and easy work, but to do it optimally of course required expertise is needed. To write business letter does not require special skills as a writer of novels, poetry, short stories or other literary works, because essentially a business letter is not a literary work. Nonetheless, to wite a good business letter is often not as simple as people imagine, because there are certain rules and habits that are generally applicable and must be met by each author of the letter. Therefore, the words and sentences in the letter should be prepared effectively and efficiently. The accuracy and detail are needed to ensure the contents of the letter are intended by the sender. Therefore, the outcomes is that the teachers in SMK Muhammadiyah 4 can teach his or her students SMK Muhammadiyah 4 how to create a business letter in English that is good and right so that later after they graduate it can be applied upon entering the workforce.
\end{abstract}

Keywords: Business letter, Teacher Training, Vocational School

\begin{abstract}
ABSTRAK
Tujuan diadakannya kegiatan pengabdian masyarakat ini adalah memberikan pelatihan mengenai teknik pembuatan business letter berbahasa Inggris bagi guru SMK Muhammadiyah Slipi Jakarta. Business letter atau surat bisnis adalah surat yang digunakan oleh seseorang, lembaga organisasi atau institusi yang menyampaikan pesan-pesan bisnis secara tertulis kepada pihak lain dengan menggunakan media tertentu baik itu berupa pengiriman surat via pos, faksmilie, telepon ataupun lewat jalur internet. Kegiatan penulisan surat bisnis sekilas memang terlihat sebagai pekerjaan yang sederhana dan mudah, namun untuk melakukannya dengan optimal tentu diperlukan keahlian didalamnya. Menulis surat bisnis yang baik tidak menuntut keahlian khusus seperti seorang pengarang novel, puisi, cerpen atau karya sastra lainnya, karena pada dasarnya surat bisnis bukanlah sebuah karya sastra. Meskipun demikian, menyusun surat bisnis yang baik tidaklah sesederhana yang sering dibayangkan orang, karena ada aturan dan kebiasaan tertentu yang secara umum berlaku dan harus dipenuhi oleh setiap penulis surat. Oleh karena itu, kata-kata dan kalimat dalam surat tersebut harus disusun secara efektif dan efisien serta disusun dengan baik dan teliti. Ketelitian dan kecermatan tersebut dibutuhkan untuk menjamin ketepatan isi surat sebagaimana yang diinginkan oleh pengirimnya.Oleh karena itu luaran yang akan dihasilkan dari kegiatan pengabdian masyarakat ini adalah supaya para guru di lingkungan SMK Muhammadiyah 4 bisa mengajarkan kepada murid-murid di lingkungan SMK Muhammadiyah 4 tentang bagaimana membuat business letter berbahasa Inggris yang baik dan benar agar nantinya setelah mereka lulus bisa diaplikasikan pada saat memasuki dunia kerja.
\end{abstract}

Kata Kunci: Surat Bisnis, Pelatihan Guru, SMK

\footnotetext{
*email: rymanovia@gmail.com
} 


\section{PENDAHULUAN}

Sejarah berdirinya SMK Muhammadiyah 4 ini yaitu pada masa kepemimpinan Soekarno, setelah 5 tahun kemerdekaan Republik Indonesia, sekitar era 60-an, dimana pembangunan disegala lini dicanangkan termasuk diantaranya saat Indonesia akan menjadi tuan rumah Asian Games 1962, dibangunlah sebuah komplek olahraga senayan di atas tanah komplek penduduk yang sebagian tanah tersebut merupakan milik Sekretariat Pimpinan Muhammadiyah Senayan. Dengan dibangunnya Komplek Olah Raga Senayan, sebagian pengurus yang memiliki tempat tinggal di daerah tersebut tergusur dan berpencar dibeberapa tempat diantaranya; cipulir, tomang, slipi-kemanggisan. Berpencarnya domisili masing - masing pimpinan, maka ada inisiatif untuk mendirikan sekretariat Muhammadiyah di sektornya masing- masing terutama sektor Muhammadiyah Slipi. Atas berdirinya Pimpinan Cabang Muhammadiyah Komplek Slipi, yang awal program kerjanya adalah mensosialisasikan Muhammadiyah serta memperkuat infrastruktur sehingga program tersebut berjalan lancar, maka merambahlah keprogram pendidikan, sehingga Pimpinan Muhammadiyah Komplek Slipi dengan Majelis Pendidikan Dasar dan Menengah-nya (Majelis Dikdasmen) mencanangkan sebuah komplek perguruan yang mengajarkan ilmu - ilmu sekolah umum dipadukan dengan pendidikan agama. Konsep yang sudah matang dari program kerja Majelis Dikdasmen PCM Komplek Slipi akhirnya mendapatkan dukungan, baik secara moral, material maupun infrastruktur tanah garapan yang dulunya merupakan tanah wakaf terletak di jalan anggrek nelly murni. Sekolah ini mempunyai misi Menyiapkan siswa yang cerdas, kompetitif untuk siap memasuki dunia kerja serta mengembangkan sikap mandiri dan profesional dan siswa yang mampu mengembangkan diri untuk persaingan di dunia kerja baik nasional maupun internasional serta memilliki jiwa kewirausahaan. Kurikulum sekolah ini adalah perpaduan dari kurikulum Pendidikan Nasional, Kurikulum 2013 dan kurikulum Islam. Perbaduan kurikulum yang bertujuan as secara intelektual, emosional, dan spiritual dapat menjadi alasan utama kenapa SMK Muhammadiyah 4 dijadikan mitra kegiatan pengabdian masyarakat semester ini. Selain itu, dipilihnya SMK Muhammadiyah 4 adalah karena sekolah ini menyiapkan siswa yang mampu mengembangkan diri untuk persaingan di dunia kerja baik nasional maupun internasional serta memilliki jiwa kewirausahaan. Salah satu kemampuan yang perlu dikembangkan oleh siswa adalah kemampuan menulis surat dalam bahasa Inggris khususnya surat bisnis yang baik dan benar dan nantinya bisa di aplikasikan ketika mereka bekerja untuk instansi atau lembaga tertentu setelah lulus sekolah.

Sekolah Menengah Kejuruan (SMK) memegang peranan penting sebagai pusat pendidikan formal yang akan menciptakan tenaga-tenaga terampil. Hal ini disebabkan karena kurikulum SMK telah dirancang untuk mengantis ${ }^{1}$ ipasi berbagai perkembangan yang terjadi di dunia kerja, khususnya di dunia usaha dan industri (DUDI). Disamping itu, kurikulum SMK ini juga dapat memenuhi visi dari pendidikan nasional dalam memberdayakan semua warga negara Indonesia untuk menjadi manusia yang berkualitas sehingga mampu dan proaktif menjawab tantangan zaman yang selalu berubah. Agar terpenuhinya profesionalisme dalam dunia kerja maka Bahasa Inggris memiliki peran yang sangat penting sebagai alat komunikasi internasional baik lisan maupun tulisan. Pasal 37 Ayat (1) dalam Undang-undang Sistem Pendidikan Nasional No 20 Tahun 2003 menyebutkan bahwa bahasa asing terutama Bahasa Inggris merupakan bahasa internasional yang sangat penting kegunaannya dalam pergaulan global. Dalam pembelajarannya guru dituntut untuk melatih siswa menggunakan Bahasa Inggris baik secara lisan maupun tertulis dan tidak semata-mata mengajarkan pengetahuan tentang bahasa itu sendiri. Begitu juga di dalam asesmen, guru sangat diharapkan menilai kemampuan siswa secara otentik dalam arti disesuaikan dengan dunia kerja, baik itu penggunaan bahasa secara lisan maupun tertulis. Walaupun keempat keterampilan tersebut diintegrasikan secara seimbang saat pembelajaran Bahasa Inggris, namun guru cenderung lebih menekankan pada aspek 
keterampilan berbicara atau pembahasanpembahasan pada struktur kalimat. Keterampilan berbicara sesungguhnya bukanlah satu-satunya keterampilan yang berperan pada dunia kerja karena keterampilan menulis berbahasa Inggris juga sangat diperlukan dalam segala profesi di dunia global saat ini.

Kegiatan menulis sangat penting untuk dilatih karena kegiatan ini merupakan alat komunikasi secara tertulis dalam menyampaikan informasi, disamping untuk mendalami komponen bahasa dalam hal ini tata bahasa dan kosa kata. Sehubungan dengan itu, SMK yang khususnya termasuk dalam kelompok jurusan bisnis akan dihadapkan pada penulisan surat-surat bisnis, memo, maupun menulis laporan-laporan berbahasa Inggris di dunia usaha maupun dunia industri. Suatu organisasi atau perusahaan harus mengadakan hubungan dengan organisasi atau perusahaan lain agar aktivitas bisnisnya dapat berjalan dengan baik dan lancar. Didalam upaya menjalin dan membina hubungan tersebut surat masih memegang peranan yang penting disamping penggunaan sarana komunikasi lainnya seperti telepon, faxcimili, internet dan lainnya. Jadi yang dimaksud dengan korespondensi bisnis pada dasarnya adalah berbagai macam aktivitas pertukaran informasi dan data melalui media surat-menyurat dalam menunjang aktivitas bisnis diantara suatu perusahaan dengan perusahaan lainnya. Surat merupakan alat komunikasi tertulis yang berguna untuk menyampaikan informasi dari suatu pihak kepada pihak lain. Informasi tersebut dapat berupa pemberitahuan, pengumuman, pernyataan, permohonan, permintaan, laporan dan sebagainya. Dengan perantaraan surat, setiap orang dapat langsung berkomunikasi dengan sesamanya tanpa harus bertatap muka terlebih dahulu. Oleh karena itu, kata-kata dan kalimat dalam surat tersebut harus disusun secara efektif dan efisien serta disusun dengan baik dan teliti. Ketelitian dan kecermatan tersebut dibutuhkan untuk menjamin ketepatan isi surat sebagaimana yang diinginkan oleh pengirimnya.

Surat memiliki ciri khas sendiri dalam berkomunikasi, komunikasi menggunakan surat cenderung membutuhkan penggunaan bahasa secara baik. Sebagaimana kita ketahui penggunaan bahasa yang baik diperlukan dalam menulis isi surat. Kendala yang sering muncul pada penulisan surat adalah latar belakang pengetahuan siswa di bidang linguistik dan struktur kalimat masih sangat kurang dan kemampuan diri siswa serta kesadaran siswa akan pentingnya keterampilan menulis masih rendah. Untuk mengatasi masalah-masalah tersebut maka guru seyogyanya menerapkan model pembelajaran inovatif yang bisa lebih memotivasi siswanya dalam memecahkan persoalan-persoalan yang berkaitan dengan dunia nyata.

Tujuan kegiatan pengabdian masyarakat ini adalah memberikan pelatihan bagi guru SMK Muhammadiyah 4 dalam hal menulis surat bisnis dengan membekali guru pengajarnya mengenai cara menulis surat bisnis karena surat bisnis merupakan salah satu ketrampilan penting dalam bidang penulisan. Kegiatan pengabdian masyarakat ini diharapkan dapat memberikan pengetahuan mengenai tata cara penulisan surat bisnis yang baik dan benar sehingga guru SMK Muhammadiyah 4 bisa mengajarkannya pada siswa sehingga kemampuan siswa dalam hal menulis umumnya atau menulis surat bisnis khususnya dapat tergali dengan baik.

\section{METODE PELAKSANAAN}

Pemilihan mitra dalam kegiatan pengabdian masyarakat ini adalah berdasarkan kebutuhan para guru mengenai tata cara penulisan surat bisnis dalam bahasa Inggris yang baik dan benar. Kemampuan untuk merangkai kata dalam surat yang baik dan santun tentunya merupakan sebuah keahlian penting yang patut dimiliki oleh siswa-siswi SMK khususnya yang biasanya setelah lulus ingin segera menerapkan ilmu yang telah dipelajarinya didunia kerja.

Pelatihan penulisan Business Letter (Surat Bisnis) berbahasa Inggris akan mengacu pada The AMA Handbook of Business Letter $3^{\text {rd }}$ edition (2002) yang telah merangkum cakupan yang ditanyakan dalam penulisan Business Letter berbahasa Inggris diantaranya:
1. Letter
2. Memo
3. Fax
4. Email

Dalam pelaksanaan pengabdian masyarakat ini digunakan:

1. Metode pelatihan yang dilakukan untuk menerapkan tehnik penulisan business letter ini terdiri dari: metode diskusi, pair work, dan praktik.

2. Kegiatan pelatihan ini terdiri dari: 
a. Penjelasan tentang tehnik penulisan business letter untuk guru dan staff.

b. Pemberian modul sebagai pedoman pelatihan.

c. Pelatihan (praktik) dengan materi: letter, memo, fax, and email.

3. Pelatihan tehnik penulisan business letter bagi guru dan staff dilakukan dalam 4 kali. Pertemuan (1 x 2 jam). Pelatihan dilakukan sesudah jam kerja agar tidak mengganggu jalannya proses belajar mengajar.

\section{HASIL DAN PEMBAHASAN}

Bahasa Inggris memiliki peran yang sangat penting sebagai alat komunikasi internasional baik lisan maupun tulisan. Pasal 37 Ayat (1) dalam Undang-undang Sistem Pendidikan Nasional No 20 Tahun 2003 menyebutkan bahwa bahasa asing terutama Bahasa Inggris merupakan bahasa internasional yang sangat penting kegunaannya dalam pergaulan global. Dalam pembelajarannya guru dituntut untuk melatih siswa menggunakan Bahasa Inggris baik secara lisan maupun tertulis dan tidak semata- mata mengajarkan pengetahuan tentang bahasa itu sendiri. Begitu juga di dalam asesmen, guru sangat diharapkan menilai kemampuan siswa secara otentik dalam arti disesuaikan dengan dunia kerja, baik itu penggunaan bahasa secara lisan maupun tertulis. Pada Kurikulum Tingkat Satuan Pendidikan (KTSP) di sekolah-sekolah kejuruan, pembelajaran Bahasa Inggris dibagi menjadi empat keterampilan pokok yang harus dipelajari oleh siswa meliputi: keterampilan mendengarkan, berbicara, membaca, dan menulis. Keempat keterampilan ini dikaitkan dengan kehidupan sehari-hari, pekerjaan, dan keprofesi- an secara kontekstual sesuai dengan tingkat pendidikan siswa. Hal ini sesuai dengan isi dari KTSP di sekolah kejuruan dimana siswa diharapkan mampu mengungkapkan makna secara tertulis dalam wacana interpersonal dan transaksional baik secara formal maupun informal. Pegungkapan makna tersebut dapat disampaikan berupa permintaan ataupun perintah yang berkaitan dengan kehidupan sehari-hari, pekerjaan, dan keprofesian.

Walaupun keempat keterampilan tersebut diintegrasikan secara seimbang saat pembelajaran Bahasa Inggris, namun guru cenderung lebih menekankan pembahasanpembahasan pada struktur kalimat dan tata bahasa atau aspek keterampilan berbicara saja. Hal ini disebabkan oleh tes-tes dari pusat yang cenderung mengacu pada struktur kalimat dan tata bahasa serta pandangan umum bahwa komunikasi adalah penyampaian lisan saja. Keterampilan berbicara sesungguhnya bukanlah satu-satunya keterampilan yang berperan pada dunia kerja karena keterampilan menulis berbahasa Inggris juga sangat diperlukan dalam segala profesi di dunia global saat ini. Kegiatan menulis sangat penting dilatihkan karena kegiatan ini merupakan alat komunikasi secara tertulis dalam menyampaikan informasi, disamping untuk mendalami kompo- nen bahasa dalam hal ini tata bahasa dan kosa kata. Sehubungan dengan itu, SMK yang khususnya termasuk dalam kelompok jurusan bisnis akan dihadapkan pada penulisan surat-surat bisnis, memo, maupun menulis laporan-laporan berbahasa Inggris di dunia usaha maupun dunia industri.

Surat merupakan bagian yang tidak terpisahkan dari aktivitas manusia pada zaman modern ini. Didorong oleh tuntutan kebutuhan ekonomi dan sosialnya, manusia akan menjalin hubungan yang semakin luas dengan berbagai individu, baik yang berada disekitarnya maupun ditempat lain. Suatu organisasi atau perusahaan harus mengadakan hubungan dengan organisasi atau perusahaan lain agar aktivitas bisnisnya dapat berjalan dengan baik dan lancar. Didalam upaya menjalin dan membina hubungan tersebut surat masih memegang peranan yang penting disamping penggunaan sarana komunikasi lainnya seperti telepon, faksimil, internet dan lainnya. Jadi yang dimaksud dengan korespondensi bisnis pada dasarnya adalah berbagai macam aktivitas pertukaran informasi dan data melalui media surat-menyurat dalam menunjang aktivitas bisnis diantara suatu perusahaan dengan perusahaan lainnya. Surat merupakan alat komunikasi tertulis yang berguna untuk menyampaikan informasi dari suatu pihak kepada pihak lain. Informasi tersebut dapat berupa pemberitahuan, pengumuman, pernyataan, permohonan, permintaan, laporan dan sebagainya. Dengan perantaraan surat, setiap orang dapat langsung berkomunikasi dengan sesamanya tanpa harus bertatap muka terlebih dahulu. Oleh karena itu, kata-kata dan kalimat dalam surat tersebut harus disusun secara efektif dan efisien serta disusun dengan baik dan teliti. Ketelitian dan kecermatan tersebut dibutuhkan untuk menjamin ketepatan 
isi surat sebagaimana yang diinginkan oleh pengirimnya.

Hasil menunjukkan bahwa guru telah menyiapkan materi-materi yang berhubungan tata cara pembuatan surat bisnis yang sesuai dengan dunia kerja untuk siswa di dalam kelas. Sehingga siswa mampu menuangkan, mengembangkan, dan mengorganisasikan ideidenya kedalam bentuk tulisan dengan lancar, lentur, dan keasliannyapun dapat dipertanggungjawabkan.

Sehingga, luaran yang ditemukan dari pelatihan

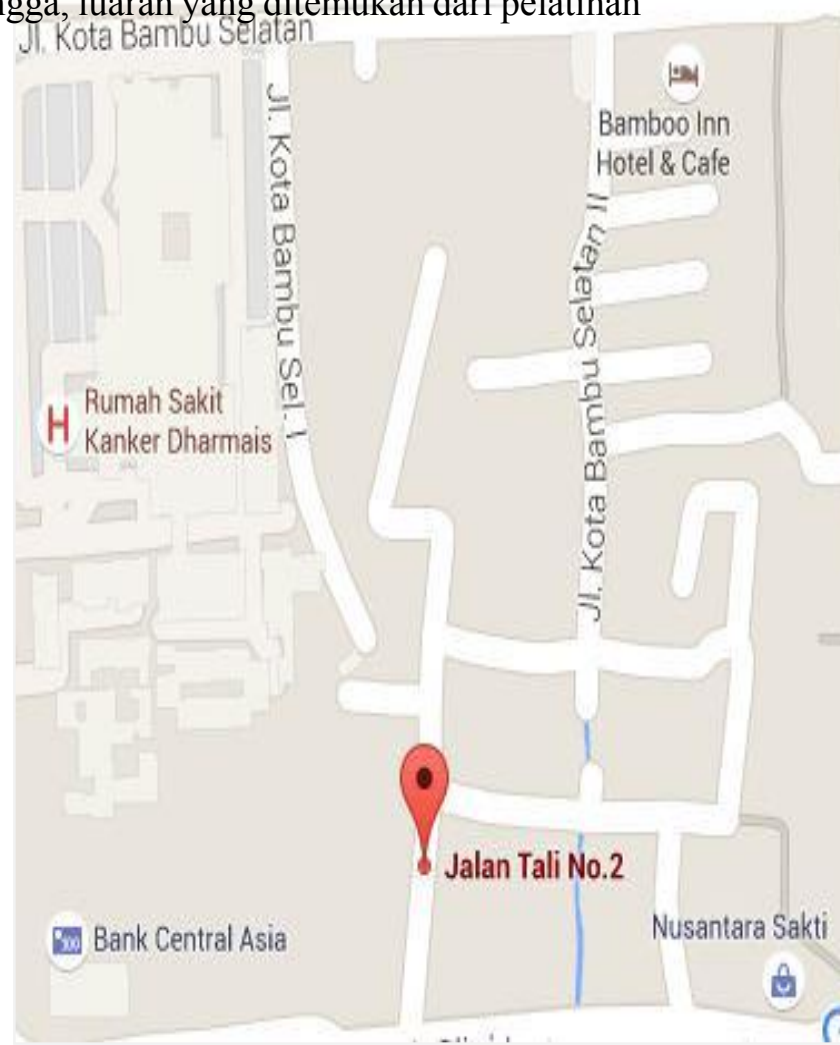

di SMK Muhammadiyah 4 pemahaman tentang pembuatan surat bisnis dalam bahasa Inggris yang nantinya dapat dimasukkan ke dalam pelajaran bahasa Inggris di SMK 4 Muhammadiyah Slipi. Secara khusus, pelatihan ini membahas tentang pembuatan surat bisnis dalam bahasa Inggris, Pelatihan ini diharapkan mampu memberi manfaat sebagai referensi bagi para guru dan Staff di SMK 4 Muhammadiyah dalam membuat surat bisnis (business letter) dalam bahasa Inggris.

Adapun sesi-sesi dokumentasi kegiatan pelatihan ini adalah sebagai berikut:

Gambar 1. Peta Wilayah Lokasi Pelatihan Guru-Guru SMK Muhammadiyah 4 Slipi Jakarta Barat Sumber: Peniliti 


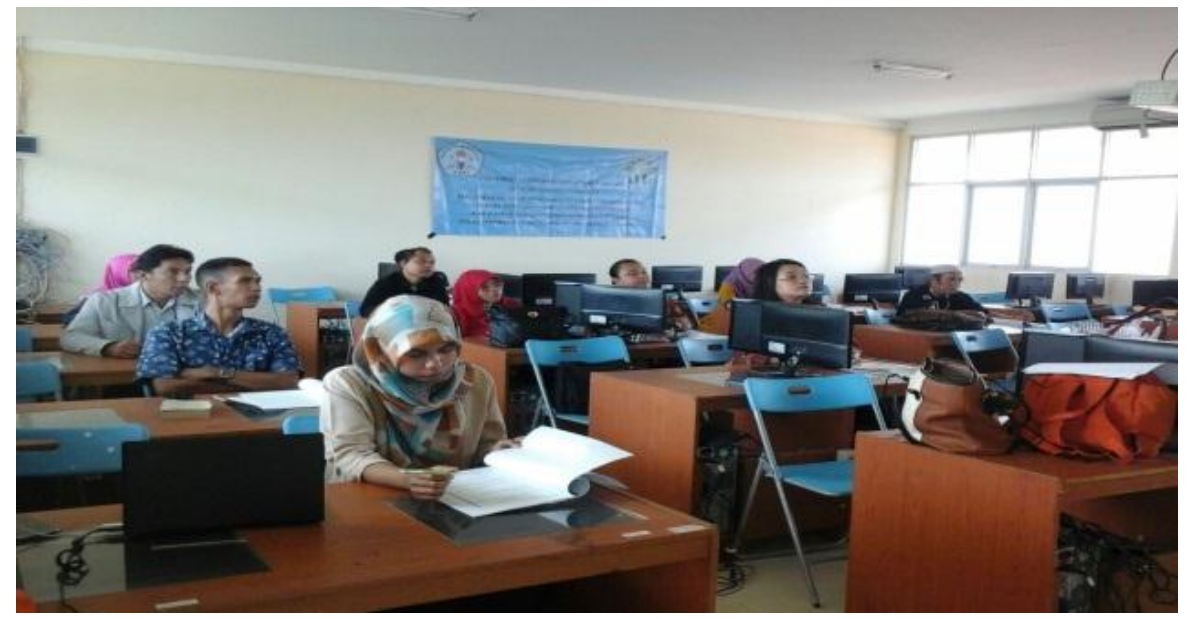

Gambar 2. Pelaksanaan Pelatihan di SMK Muhammadiyah 4 Slipi Jakarta Barat Sumber: Peneliti

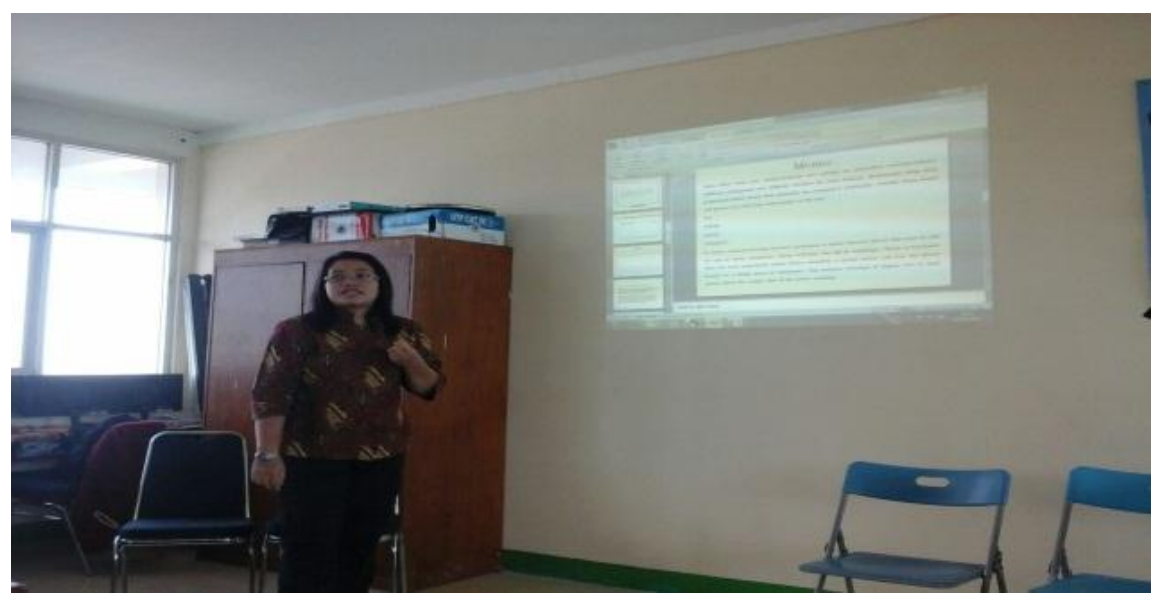

Gambar 3. Pelaksanaan Pelatihan di SMK Muhammadiyah 4 Slipi Jakarta Barat Sumber: Peneliti

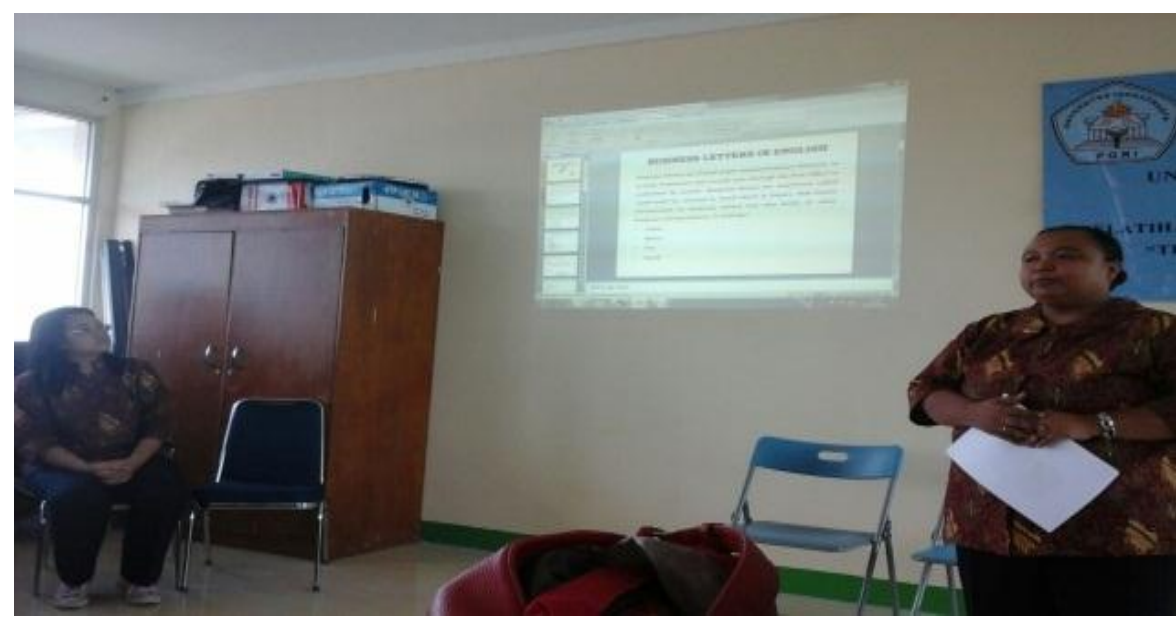

Gambar 4. Pelaksanaan Pelatihan di SMK Muhammadiyah 4 Slipi Jakarta Barat Sumber: Peneliti 


\section{SIMPULAN DAN SARAN}

Berdasarkan hasil dan pembahasan, maka kami dapat menguraikan simpulan sebagai berikut:

1. Pemberian pelatihan bagi guru dan staff di SMK Muhammadiyah 4 bertujuan untuk melatih guru dan staf agar dapat menulis business letter dalam bahasa Inggris dengan baik dan benar. Kegiatan pengabdian masyarakat ini diharapkan dapat memberikan motivasi terutama guru non pendidikan bahasa Inggris dan staff yang memiliki pengetahuan bahasa Inggris yang masih kurang terutama dalam penulisan surat menyurat menggunakan bahasa Inggris.

2. Metode pelatihan yang dilakukan untuk menerapkan tehnik penulisan business letter ini terdiri dari: metode diskusi, pair work, dan praktik. dilakukan dalam 4 kali.

3. Pertemuan ( 1 x 2 jam). Kegiatan pelatihan ini terdiri dari: penjelasan tentang tehnik penulisan business letter untuk guru dan staff, pemberian modul sebagai pedoman pelatihan, dan pelatihan (praktik) dengan materi: letter, memo, fax dan email. Pelatihan dilakukan sesudah jam kerja agar tidak mengganggu jalannya proses belajar mengajar.

Dari pemberian pelatihan ini dapat disimpulkan bahwa peserta mendapatkan pengetahuan dasar tentang berkomunikasi dalam bahasa Inggris dan dapat mempraktikkannya dalam berbagai tema dan situasi. Peserta merasa senang karena teknik yang digunakan dalam pelatihan sangat menyenangkan dan fokus kepada praktik kemampuan berbicara sehingga mereka dapat langsung mempraktikannya secara berpasangan atau berkelompok. Modul yang diberikan sangat mudah dipahami dan dapat membantu peserta untuk belajar secara mandiri di rumah.

Berdasarkan pelatihan yang telah diberikan terhadap guru baik non pendidikan bahasa Inggris, bahasa Inggris dan staff di SMK Muhammadiyah 4 Slipi Jakarta Barat, maka ada beberapa hal yang dapat diperhatikan yaitu:

1. Kepala Sekolah SMK Muhammadiyah 4 diharapkan lebih proaktif dalam mensosialisasikan program pelatihan tehnik penulisan business letter kepada para guru dan staff sehingga mereka juga dapat meningkatkan kemampuan menulis surat dalam bahasa Inggris.

2. Memberikan waktu yang lebih lama untuk program pelatihan bahasa Inggris selanjutnya sehingga lebih banyak lagi materi yang dapat diajarkan kepada peserta.

\section{DAFTAR PUSTAKA}

Nikolaenko.(2008). Business English Textbook.Tomsk Polytechnic University Publishing House

Seglin, Jeffry L.(2002). The AMA Handbook of Business Letter $3^{\text {rd }}$ ed. NY: AMACOM

Talbot, Fiona. (2009). How to Write Effective Business English. London: Kogan Page 